Fish and Fisheries

March 2018, Volume 19, Issue 2, Pages 390-398

http://dx.doi.org/10.1111/faf.12263

http://archimer.ifremer.fr/doc/00416/52784/

(C) 2017 John Wiley \& Sons Ltd

\title{
How to provide scientific advice for ecosystem-based management now
}

\author{
Trenkel Verena ${ }^{1, *}$ \\ ${ }^{1}$ Ifremer; Nantes Cedex 3, France \\ *Corresponding author :Verena Trenkel, email address : Verena.Trenkel@ifremer.fr
}

\begin{abstract}
:
$\mathrm{n}$ this paper, I argue that we have at hand what is needed to provide scientific advice for ecosystembased management of small pelagics and other species groups now. The ingredients for this advice are (i) large marine ecosystems as spatial management units; (ii) maintaining ecosystem productivity and exploiting at multispecies maximum yield as overarching management objectives; (iii) assessment of ecosystems by evaluating changes in primary productivity; (iv) an operational management procedure in which single-species catch proposals are adjusted to ecosystem productivity using a set of control rules. Inspection of historic landings for small pelagics and other small species in the Northeast Atlantic (ICES area) reveals that most likely fisheries exploitation does not, and never did, exceed system productivity in most LMEs and is therefore overall sustainable, although not necessarily for individual stocks.
\end{abstract}

Keywords : EBFM, Fisheries management, fisheries yield, primary production 


\section{State of affairs}

Ecosystem-based management $(\mathrm{EBM})$ is part of the continuum from single species fisheries management to the management of multiple sectors and objectives (Dolan et al., 2016). Marine ecosystems are subject to a multitude of anthropogenic threats (e.g. Halpern et al. (2007), Lorance et al. (2009)). Hence EBM of small pelagics though centred on a specific ecosystem component is embedded in a wider management approach. However, not all anthropogenic activities impact all ecosystem types and components (Halpern et al., 2007), allowing for EBM of small pelagics by only considering relevant pressures, mainly fishing, and some indirect effects.

The political framework for ecosystem-based fisheries management in Europe has been in place for some time now (Jennings and Rice, 2011). Nevertheless, as pointed out by Jennings and Rice (2011) progress is piece meal, not only because of different legislations taking place at different governmental levels (Common Fisheries Policy - CFP European Union (2013) at EU level and environmental policy such as the Marine Strategy Framework Directive MSFD (European Union, 2008) at the Member State level (Ramirez-Monsalve et al., 2016a), but also unwillingness of EU member states to accept short term transition costs and to transfer tactical decision-making to regional bodies (Jennings and Rice, 2011).

Numerous authors have reviewed progress and listed impediments, challenges, and needs on the way to EBM, e.g. (Ramirez-Monsalve et al., 2016b, Cowan et al., 2012, Link and Browman, 2017). Here I will take a different view and explore what is already available or could be available with little effort, taking small pelagics in the NE Atlantic (broadly the ICES area) as example. Indeed, if Patrick and Link (2015) are correct and many obstacles to progress towards EBM are myths, the ingredients for EBM of small pelagics are within reach. I argue that this is indeed the case though the recipe for putting it all together is still missing 
some instructions. However, given the long history of fisheries management, long tested procedures might come to new use.

To prepare for applying EBM to small pelagics in the NE Atlantic I will consider four steps which are inspired by Fogarty (2014): i) selection of spatial management units; ii) establishment of management objectives and reference points; iii) assessment of system status; and iv) selection of management procedures. For each step I consider operational procedures which could be implemented rapidly to provide scientific advice for EBM of small pelagics, but not considering the full complexity of governance related issues (RamirezMonsalve et al., 2016a), and only partially social and economic dimensions.

\section{Spatial units}

In Europe, the regions defined for fisheries management (CFP) and wider marine ecosystem management (MSFD) differ. For the MSFD these are regional seas, while for the CFP the relevant geographical areas depend on the spatial scale of each stock, including interactions with other species (European Union, 2013). Jennings and Rice (2011) proposed to harmonise the two sets of regions at the smallest scale at which several member states contribute to management. Though, ultimately fisheries catches are limited by productivity (Chassot et al., 2010) but also the importance of benthic pathways with potentially higher trophic efficiency compared to pelagic pathways (Stock et al., 2017).

System production is modulated on a rather large scale, making large marine ecosystems (LME) the appropriate spatial scale for ecosystem level assessment and management (Sherman and Duda, 1999, Sherman, 1991). Yet, the spatial scale of the distribution of certain small pelagic populations such as blue whiting (Micromestitius poutassou, Gadidae) or NE Atlantic mackerel (Scomber scombrus, Scombridae) is even larger (see review in Trenkel et 
al. (2014)). Currently NE Atlantic mackerel occupy at least five LMEs as they move around for spawning and feeding. As a result there is a strong seasonal pattern to the spatial distribution of mackerel catches (e.g. ICES (2014)), with the biomass caught in a given LME not necessarily having been produced there. This has to be borne in mind when developing EBM at the LME level.

Environmental conditions affect life history parameters, spatial distributions and migration patterns of many small pelagic stocks in the North Atlantic (Trenkel et al., 2014, Rose, 2005, Peck et al., 2013). LMEs will probably not be large enough to buffer against all environmental change induced distribution variations, providing another reason for not considering LMEs as spatial units cast in stone.

\section{Management objectives and reference points}

Single stock management objectives are embedded within wider EBM objectives. In Europe this is legislated by the CFP with its maximum sustainable yield (MSY) objectives for exploited species and the MSFD specifying wider ecosystem health objectives. Both CFP and MSFD define higher level strategic goals, which for particular areas and fisheries need to be broken down into lower level operational objectives (ICES, 2013, Jennings, 2005). Trenkel et al. (2015) attempted to identify relevant operational ecological and economic objectives for specific small pelagic stocks and areas in the NE Atlantic based on a stakeholder consultation and the literature. A formal process would be needed to validate and move these identified potential operational objectives from the status of a scientific proposal to agreed and legislated management.

As MSY is a stated objective of the CFP, the legislative framework is already in place. Considering MSY on the ecosystem level leads to multispecies maximum sustainable yield 
(MMSY). Global MMSY for all species, not only assessed and management species, is determined by system productivity though pelagic species might create connections between LMEs. Maintaining system-wide productivity within defined bounds was proposed by Fogarty (2014) as the central ecological management objective of EBM of fisheries. Aiming for MMSY combined with MSY for individual stocks (or at least some upper exploitation limit preventing extinction of bycaught species) could be a way to achieve this ecological objective at the same time as the economic objective of maximum yield. This idea is not new. For example, a multispecies optimum yield range has already been implemented for Alaska groundfish fisheries in the 1980s (Witherell et al., 2000).

Rice and Duplisea (2014) evaluated (using expert judgement) the expected performance of a range of management strategies for small pelagics (forage fish) in terms of robustness to natural variations, risk of creating ecosystem changes and socio-economic criteria. The strategy applying fixed $\mathrm{F}$ (corresponding to $\mathrm{F}_{\mathrm{MSY}}$ ) for each species did not perform best for all criteria, but neither did any of the other strategies. Thus, there are no strong arguments to my knowledge against combining single species MSY with a global MMSY strategy as proposed here.

MMSY depends on system productivity but also fisheries exploitation patterns, such as size selectivity (Jennings and Collingridge, 2015). If MMSY for all species or a subset of species, e.g. small pelagics, is to be used as a limit reference point for catches (landings + dead discards), robust estimates are needed as well as the level of uncertainty. Though system productivity might vary somewhat between years, assuming a constant MMSY value might be appropriate for the medium term ( $<5$ years) perspective required for providing scientific tactical management advice needed for individual stock quota setting. Thus MMSY estimates based on recent conditions assuming equilibrium might be adequate for many ecosystems, but 
see proposal below. Further, while such an estimate of MMSY is needed for small pelagics or other exploited groups I argue that it does not have to be too precise to be useable.

Numerous mechanistic ecosystem models exist that could be used for estimating MMSY. They differ in details but generally adopt a size- and traits-based approach, e.g. Harfoot et al. (2014), Jennings and Collingridge (2015), Jacobsen et al. (2017). A size or functional group resolution is important given fisheries are size and group selective, with different gears generally targeting different size ranges and species/groups (Fauconnet et al., 2015, Daurès et al., 2009, Trenkel et al., 2013). Also, technical measures regulating size selection of fishing gears are an important management tool in many jurisdictions around the world. Lastly, the model needs to be parameterised to account for ecosystem specific productivity.

Jennings and Collingridge (2015) using a size- and traits-based macroecological equilibrium model estimated a range of MMSY values for all LMEs worldwide. In this model the main drivers of between LME variations in sustainable fish yield were sea surface temperature and primary production. MMSY estimates strongly depended on the assumed fishing selection pattern (Jennings and Collingridge, 2015). In one fishing selection scenario (scenario A) the minimum size of any individual targeted was set at $8 \mathrm{~cm}$ and fishing mortality decreased strongly with maximum species size. In another fishing selection scenario (C) the minimum size of an individual targeted was reduced to $7 \mathrm{~cm}$ and individuals larger than $48 \mathrm{~cm}$ of any species were targeted with the same relatively high fishing mortality rate. MMSY estimates for small species (size class $<1 \mathrm{~kg}$ maximum weight), to which belong small pelagics but also small benthivores, differed for the two fishing selectivity scenarios for most LMEs (see application section). 


\section{System status}

The system whose status is to be assessed includes both the ecosystem and the socioeconomic system. The aim of the assessment is to evaluate whether the status of different system components corresponds to the stated management objectives. Levin et al. (2009) refer to this approach as an integrated ecosystem assessment.

For single stock assessments the assessment methods commonly used range from fitting population dynamics models to estimate stock biomass and fishing mortality (aka data rich methods) to investigating times trends in various stock indicators, e.g. biomass indices from surveys (aka data poor methods). An equivalent range of methods is available for ecosystem component assessments, from quantitative models, e.g. (Hollowed et al., 2011), to indicator time trends (Trenkel and Rochet, 2003, Shephard et al., 2014). Shephard et al. (2014) calculated indicators for the small pelagic fish community using single stock assessment outputs, which means only assessed species were considered, but luckily they are also the most abundant small pelagic species. Shephard et al. (2015) coined the term surveillance indicators for indicators for which there is no known causal link between anthropogenic pressure and status and for which reference points cannot be defined. For this class of indicators Rochet et al. (2005) proposed to use the direction of time trends to detect change of status or stability instead of actual status established by comparison to reference points as done for single species stock assessments (e.g. Bmsy, Fmsy).

Correct understanding of single species population dynamics is an important condition for efficient management of fisheries and other anthropogenic activities (Mace, 2004). However, biased stock estimates can be caused by imprecise data or incorrect model assumptions (model structure, parameter values). Environmental conditions but also species interactions influence population dynamic of small pelagics, see review in Trenkel et al. (2014), and single 
species reference points (Collie and Gislason, 2001). Assuming fixed population dynamics model parameters when in reality they vary might also lead to biased stock perception. SkernMauritzen et al. (2016) reviewed over 1250 stock assessment models applied worldwide for use of environmental information (Chl a, predation mortality) and found only 24 cases with such use. To overcome the shortcoming of assuming fixed natural mortality a range of multispecies models have been developed, though they are more often used for providing ecosystem context rather than scientific management advice (see review in Collie et al. (2016)). For habitats the relevant characteristics to be assessed depend on the type. DickeyCollas et al. (2017) proposed that pelagic habitat in good status allowed all dependent species to close their life cycle. Most small pelagic species are water column spawners with some exceptions, e.g. herring (Clupeus harengus, Clupeidae) and caplin (Mallotus villosus, Osmeridae). For these species availability of appropriate spawning habitats might become a limiting factor.

The assessment of the economic and social status of fisheries is generally carried out separately from the ecological status assessment using socio-economic indicators (Daurès et al., 2013, Ceriola et al., 2008, Gasalla et al., 2010). In Europe, social and economic fisheries related data are routinely collected and summaries are published annually (STECF, 2016). Economic return is an important indicator for assessing the sustainability of fishing fleets and thus dependent jobs. It can vary between fleets and years due to different factors including variable fuel costs (Trenkel et al., 2013).

Lastly I would like to stress an important point. For providing scientific advice for a particular ecosystem component such as small pelagics we only need to assess factors relating small pelagics to the selected management objective which is maintaining system wide productivity while exploiting at MMSY. 


\section{Management procedure}

Single species management needs to be extended to accommodate the wider EBM objectives. A simple pragmatic way to do this is outlined in figure 1 . The basic idea is to first carry out traditional single species stock assessments and short term projections possibly using multispecies models and including environmental drivers as relevant, to propose a first set of future catch options (steps 1. and 2. in Fig. 1). These catch options are subsequently revised (step 3.) to account for ecosystem considerations. The final result is ecosystem-based single species catch advice (step 4.). Assuming an MSY framework for single species, the initial catch proposals are based on using single species MSY reference points.

There are two spatial domains for the four steps (continuous and dashed boxes in Fig. 1): stock areas for single species considerations (steps 1., 2. and 4.) and LMEs for the catch proposal adjustments (step 3.). Ways to handle the transitions are discussed below.

Ecosystem considerations are included in two additional steps, both on the LME scale. First, recent changes in factors affecting MMSY such primary production and/or temperatures are assessed (step I. in Fig. 1). For primary production model derived estimates or an index derived from in situ or satellite observations could be used. If there was no time trend and little interannual variation, the upper limit of multispecies total allowable catch (MTAC), including assessed and non-assessed species, is set to the reference point MMSY discussed above (step II); similarly if the primary production index showed an increasing trend. If in contrast the index showed a decrease or strongly varied between years, the value of MTAC should be smaller than MMSY calculated previously. In the later case for specifying the amount of reduction a total harvest control rule is used, similar to harvest control rules employed for setting single species catch quotas. For example, assuming a linear relationship 
between primary production and fish production as has been commonly made (e.g. Iverson (1990)) the rule could be

$$
\mathrm{MTAC}_{t+1}=0.9 \Delta P P_{t} \mathrm{MMSY}
$$

where $\triangle P P_{\mathrm{t}}$ is the relative decrease of primary production and the 0.9 coefficient (or any other value) represents a precautionary buffer. Management strategy evaluation (MSE) simulations could be used to test the robustness of the selected rule. To carry out this MSE a sufficiently comprehensive ecosystem model is of course needed.

A major change in fisheries size selectivity will also impact the long term MMSY value. Such changes could be driven by changes in mesh sizes or changing use of certain gear types, e.g. decreasing use of bottom trawls. If big changes occurred it is unlikely that MMSY values could be translated with simple rules into MTAC values, rather the model(s) used for estimating MMSY would need to be run.

Having identified the multispecies total allowable catch MTAC by LME, we need to come back to the single species catch proposal revisions (step 3.). The first action is to distribute stock catch proposals between LMEs to be able to compare them to MTAC values for the same areas. In the absence of other information it might be sufficient to assume some temporal stability in spatial distributions and use the average proportion of landings by LME for the most recent (2-5) years to distribute stock specific catch proposals between LMEs. Then another control rule is called for, which will probably be LME specific. This control rule could use biological, fisheries, statistical or economic criteria or a combination of them to adjust single species catch proposals for $\operatorname{LME} j$

$$
\begin{gathered}
\operatorname{Catch}_{i, j, t+1}^{*}=f_{j}\left({\text { criteria }) \text { Catch }_{i, j, t+1}}\right. \\
\text { conditional on } \sum_{i} \operatorname{Catch}_{i, j, t+1}^{*} \leq \mathrm{MTAC}_{t+1}
\end{gathered}
$$


where $\operatorname{Catch}_{i, j, t+1}$ is the initial catch proposal for species $i$ in LME $j$ for year $t+1$ (or any other future year) and $\operatorname{Catch}_{i, j, t+1}^{*}$ is the ecosystem-based adjusted catch proposal. Note that the sum in eq. 2) is over all exploited species, not only assessed species. For species without catch quotas an average of recent catches could be used, including an estimate of dead discards for species entirely discarded.

Biological criteria used in eq. 2) could include reducing catch quota more for more long-lived species, which would have the added benefit to be able to wait to appraise incoming recruitment, and/or ensuring an appropriate ratio between landings of small (forage) species and larger piscivores. Fisheries related criteria could consider technical interactions to avoid/reduce discards. This might be less relevant for small pelagics as most fishing operations have few bycatch species (Cornou et al., 2016). Statistical criteria could include reducing proposed catches more for stocks with more uncertain stock assessments or uncertain short term projections (which are underlying catch proposals). Economic criteria could include species sales values by reducing catches for lower value species more, for example sardine more than anchovy, or fleet economic returns, reducing catches more for species targeted by more/less profitable fleets or by fleets burning more fuel per euro gained.

Once all catch proposals have been adjusted to LME production, ecosystem-based single species adjusted catch proposals are obtained by summation over LMEs (step 4.)

$$
\operatorname{Catch}_{i, t+1}^{*}=\sum_{j} \operatorname{Catch}_{i, j, t+1}^{*}
$$

Multiannual multispecies management plans (MAP) are considered a way forward for implementing EBM, though there are many challenges on the way (Ramirez-Monsalve et al., 2016a). For implementing the proposed management procedure, the MMSY reference point and the two control rules (eq $1 \& 2$ ) could be included in a legislated MAP. As the proposed procedure is rather generic, LME and species group specific adaptions are easy to make. 


\section{Application}

The proposed approach for EBM is illustrated for small pelagics in the NE Atlantic (restricted to the ICES area) using historic landings. All major small pelagics stocks in this area are evaluated and managed by annual fishing quotas.

International landings by LME were extracted for the period 1950 to 2015 from the landings data based held by ICES (http://www.ices.dk/marine-data/dataset-collections/Pages/Fishcatch-and-stock-assessment.aspx). After removing brackish and freshwater species, species were roughly categorised into small species (minimum size $>7 \mathrm{~cm}$ and maximum size $<1 \mathrm{~kg}$ ) and medium sized species (1-10 kg). Small species were further subdivided into small pelagics and small benthivores, see species list in online supplementary material. Although landings do not represent the full catches due to discards, this data set should provide a rough idea of how to apply the proposed method.

For each LME, MMSY values estimated by Jennings and Collingridge (2015) for small individuals $(<1 \mathrm{~kg}$ and $>$ minimum target size) for two fisheries exploitation patterns (scenario $\mathrm{A}$ and $\mathrm{C}$ in the original paper) were kindly provided by $\mathrm{S}$. Jennings. Under a single species MSY approach fishing mortality decreases with species size, hence as MSY management became implemented fishery exploitation patterns should have moved away from scenario $\mathrm{C}$ (continued high fishing mortality for larger species) towards scenario A (decreasing fishing mortality with species size). Assuming fisheries exploitation patterns were closer to scenario $\mathrm{C}$ at the beginning of the period and to scenario A towards the end and system productivity remained stable over the whole time series, historic landings in most LMEs in the NE Atlantic were smaller than the reference values in the early period and approaching them in recent decades (Fig. 2). The exceptions were the North Sea in the intermediate period, the Faroe 
plateau more recently and the Baltic Sea over the whole period. This could either be due to the model (formulation, parameter values, environmental drivers) being inappropriate, the assumed fishing exploitation patterns being unrealistic or exploitation really not being sustainable. The later explanation seems plausible for the North Sea where a strong decrease in sandeel landings (Ammodytes spp, Ammodytidae) pushed total landings under the reference value in the early 2000s while on the Faroe plateau high and variable blue whiting landings explain the recent overshoot. As the blue whiting stock occupies several LMEs, these variations indicate more likely changes in spatial distribution rather than local overexploitation. More generally, this suggests that the Faroes plateau LME is an inappropriate spatial scale for evaluating whether fisheries of small pelagics exceed system productivity. For the Baltic Sea the explanation of continued unsustainable exploitation are supported by the model results reported by Jacobsen et al. (2017). These authors found that the fishing exploitation pattern for the Baltic Sea was inefficient as fishing mortalities were too high. However, it is also possible that the MMSY estimates were inappropriate, for example due to the underlying biogeochemical model underestimating primary production in the enclosed Baltic Sea.

To evaluate the potential imbalance of landings for small and medium sized (1-10 kg) species, the ratio of small to medium MMSY values was calculated using worldwide average MMSY values (table 5 in Jennings and Collingridge (2015)). These ratios were 6.5 and 5.5 for fishing selectivity scenario A and C, respectively. Calculating the same ratio for landings revealed that fisheries exploitation in most LMEs was dominated by medium sized species in earlier years, but increased towards the reference ratio in recent years. This might indicate that selectivity patterns became more balanced over time, i.e. closer to system productivity size structures. 
In conclusion, based on this rough assessment, fisheries exploitation of small species, including small pelagics, in most LMEs in the ICES area in the NE Atlantic did not seem to have exceed system productivity during the last 65 years, if the assumed system productivities and fisheries exploitation patterns were realistic. Hence, the ecosystem objective of maintaining productivity while maximising yield seems to have been generally met. For the Baltic Sea more detailed investigations are needed to confirm the potential overexploitation.

\section{Concluding remarks}

While we will probably never get the crystal ball needed to foresee upcoming multispecies interactions or other ecosystem or socio-economic changes, I argue that by applying the rather simple procedure outlined here we can already get on the way. The procedure combines single species stock assessment with ecosystem-level catch adjustments applying a number of control rules. Using predefined control rules has been beneficial in single stock management and might be expected to reduce conflict and trade-off discussions, for example between fisheries exploiting small pelagics and fisheries exploiting demersal species as might otherwise be expected (Ramirez-Monsalve et al., 2016a). Further, aiming to meet the management objective of maintaining ecosystem productivity means that the priorities for monitoring become well defined, i.e. parameters relevant for detecting changes in primary productivity. Monitoring needs for other ecosystem-based management objectives such as ensuring enough forage fish for dependent predators will of course be different, as will be the appropriate management measures. For example, to ensure food for breeding seabirds or marine mammals spatio-temporal fishing closures might be needed (as implemented for Alaska groundfish fisheries, see Witherell et al. 2000). Lastly, as shown by the application, 
fisheries for small pelagics in the NE Atlantic seem to be compatible with system productivities and roughly balanced between small and larger species, with the possible exception of the Baltic Sea. However, more detailed analyses possibly comparing different ecosystem models, ensuring assumed fisheries selection patterns are realistic, and dealing with discards and unexploited species are needed to confirm this result.

\section{Acknowledgement}

The thoughts expressed in this manuscript were stimulated by the ICES/PICES Symposium on "Drivers of dynamics of small pelagic neritic fish resources" to which the convenors kindly invited me. I would also like to acknowledge funding from the Eranet Cofasp project Prime Tradeoffs (ANR-15-COFA-0004-01). I am very grateful to Simon Jennings for providing the detailed MMSY estimates and Pascal Lorance and two anonymous referees for constructive comments.

\section{References}

Ceriola, L., Accadia, P., Mannini, P., Massa, F., Milone, N., Ungaro, N. (2008) A bioeconomic indicators suite for the appraisal of the demersal trawl fishery in the Southern Adriatic Sea (Central Mediterranean). Fisheries Research 92, 255-267. doi:10.1016/j.fishres.2008.01.017

Chassot, E., Bonhommeau, S., Dulvy, N.K., et al. (2010) Global marine primary production constraints fisheries catches. Ecology Letters 13, 495-505. doi:10.1111/j.14610248.2010.01443.x

Collie, J.S., Botsford, L.W., Hastings, A., et al. (2016) Ecosystem models for fisheries management: finding the sweet spot. Fish and Fisheries 17, 101-125. doi: 10.1111/faf.12093 
Collie, J.S., Gislason, H. (2001) Biological reference points for fish stocks in a multispecies context. Canadian Journal of Fisheries and Aquatic Sciences 58, 2167-2176. doi: 10.1139/f01-158.

Cornou, A.-S., Dimeet, J., Goascoz, N., Scavinner, M., Rochet, M.-J. (2016) Captures et rejets des métiers de pêche français. Résultats des observations à bord des navires de pêche professionnelle en 2015. 403pp.

Cowan, J.H., Rice, J.C., Walters, C.J., et al. (2012) Challenges for Implementing an Ecosystem Approach to Fisheries Management. Marine and Coastal Fisheries 4, 496510. doi:10.1080/19425120.2012.690825

Daurès, F., Rochet, M.-J., Van Iseghem, S., Trenkel, V.M. (2009) Fishing fleet typology, economic dependence, and species landing profiles of the French fleets in the Bay of Biscay, 2000-2006. Aquatic Living Resources 22, 535-547. doi:10.1051/alr/2009031

Daurès, F., Trenkel, V.M., Guyader, O. (2013) Modelling the cost structure of French fishing vessels in the Bay of Biscay. Fisheries Research 146, 74-85. doi:10.1016/j.fishres.2013.03.022

Dickey-Collas, M., McQuatters-Gollop, A., Bresnan, E., et al. (2017) Pelagic habitat: exploring the concept of good environmental status. ICES Journal of Marine Science 74, 2333-2341. doi:10.1093/icesjms/fsx158

Dolan, T.E., Patrick, W.S., Link, J.S. (2016) Delineating the continuum of marine ecosystembased management: a US fisheries reference point perspective. ICES Journal of Marine Science 73, 1042-1050. doi:10.1093/icesjms/fsv242

European Union (2008) Directive 2008/56/EC of the European Parliament and of the Council of 17 June 2008 establishing a framework for community action in the field of marine environment policy (Marine Stategy Framework Directive). Official Journal of the European Union 25.6.2008 L164, 19-40.

European Union (2013) Regulation (EU) No. 1380/2013 of the European Parliament and of the Council of 11 December 2013 on the Common Fisheries Policy. Official Journal of the European Union L 354, 22-61.

Fauconnet, L., Trenkel, V.M., Morandeau, G., Caill-Milly, N., Rochet, M.-J. (2015) Characterizing catches taken by different gears as a step towards evaluating fishing pressure on fish communities. Fisheries Research 164, 238-248. doi:10.1016/j.fishres.2014.11.019

Fogarty, M.J. (2014) The art of ecosystem-based fishery management. Canadian Journal of Fisheries and Aquatic Sciences 71, 479-490. doi:10.1139/cjfas-2013-0203 
Gasalla, M.A., Rodrigues, A.R., Duarte, L.F.A., Sumaila, U.R. (2010) A comparative multifleet analysis of socio-economic indicators for fishery management in SE Brazil. Progress in Oceanography 87, 304-319. doi:10.1016/j.pocean.2010.09.011

Halpern, B.S., Selkoe, K.A., Micheli, F., Kappel, C.V. (2007) Evaluating and ranking the vulnerability of global marine ecosystems to anthropogenic threats. Conservation Biology 21, 1301-1315. doi:10.1111/j.1523-1739.2007.00752.x

Harfoot, M.B.J., Newbold, T., Tittensor, D.P., et al. (2014) Emergent global patterns of ecosystem structure and function from a mechanistic general ecosystem model. Plos Biology 12. doi:10.1371/journal.pbio. 1001841

Hollowed, A.B., Aydin, K.Y., Essington, T.E., et al. (2011) Experience with quantitative ecosystem assessment tools in the northeast Pacific. Fish and Fisheries 12, 189-208. doi:10.1111/j.1467-2979.2011.00413.x

ICES (2013) Guidance on the application of the ecosystem approach to management of human activities in the European marine environment. ICES Co-operative Research Report.

ICES (2014) Report of the Working Group on Widely Distributed Stocks (WGWIDE). 971.

Iverson, R.L. (1990) Control of marine fish production. Limnology and Oceanography 35, 1593-1604. doi:10.4319/lo.1990.35.7.1593

Jacobsen, N.S., Burgess, M.G., Andersen, K.H. (2017) Efficiency of fisheries is increasing at the ecosystem level. Fish and Fisheries 18, 199-211. doi:10.1111/faf.12171

Jennings, S. (2005) Indicators to support an ecosystem approach to fisheries. Fish and Fisheries 6, 212-232. doi:10.1111/j.1467-2979.2005.00189.x

Jennings, S., Collingridge, K. (2015) Predicting consumer biomass, size-structure, production, catch potential, responses to fishing and associated uncertainties in the world's marine ecosystems. PLOS ONE 10. doi:10.1371/journal.pone.0133794

Jennings, S., Rice, J. (2011) Towards an ecosystem approach to fisheries in Europe: a perspective on existing progress and future directions. Fish and Fisheries 12, 125-137. doi:10.1111/j.1467-2979.2011.00409.x

Levin, P.S., Fogarty, M.J., Murawski, S.A., Fluharty, D. (2009) Integrated Ecosystem Assessments: Developing the Scientific Basis for Ecosystem-Based Management of the Ocean. Plos Biology 7, 23-28. doi:10.1371/journal.pbio.1000014

Link, J.S., Browman, H.I. (2017) Operationalizing and implementing ecosystem-based management. ICES Journal of Marine Science 74, 379-381. doi: 0.1093/icesjms/fsw247 
Lorance, P., Bertrand, J.A., Brind'Amour, A., Rochet, M.-J., Trenkel, V.M. (2009) Assessment of impacts from human activities on ecosystem components in the Bay of Biscay in the early 1990s. Aquatic Living Resources 22, 409-431. doi:10.1051/alr/2009049

Mace, P.M. (2004) In defence of fisheries scientists, singe-species models and other scapegoats: confronting the real problems. Marine Ecology Progress Series 274, 285291.

Patrick, W.S., Link, J.S. (2015) Myths that continue to impede progress in ecosystem-based fisheries management. Fisheries 40, 155-160. doi:10.1080/03632415.2015.1024308

Peck, M.A., Reglero, P., Takahashi, M., Catalan, I.A. (2013) Life cycle ecophysiology of small pelagic fish and climate-driven changes in populations. Progress in Oceanography 116, 220-245. doi:10.1016/j.pocean.2013.05.012

Ramirez-Monsalve, P., Raakjaer, J., Nielsen, K.N., et al. (2016a) Institutional challenges for policy-making and fisheries advice to move to a full EAFM approach within the current governance structures for marine policies. Marine Policy 69, 1-12. doi:10.1016/j.marpol.2016.03.016

Ramirez-Monsalve, P., Raakjaer, J., Nielsen, K.N., et al. (2016b) Ecosystem Approach to Fisheries Management (EAFM) in the EU - Current science-policy-society interfaces and emerging requirements. Marine Policy 63-92. doi:10.1016/j.marpol.2015.12.030

Rice, J., Duplisea, D. (2014) Management of fisheries on forage species: the test-bed for ecosystem approaches to fisheries. ICES Journal of Marine Science 71, 143-152. doi:10.1093/icesjms/fst151

Rochet, M.-J., Trenkel, V.M., Bellail, R., et al. (2005) Combining indicator trends to assess ongoing changes in exploited fish communities: diagnostic of communities off the coasts of France. ICES Journal of Marine Science 62, 1647-1664. doi:10.1016/j.icesjms.2005.06.009

Rose, G.A. (2005) On distributional responses of North Atlantic fish to climate change. ICES Journal of Marine Science 62, 1360-1374. doi:10.1016/j.icesjms.2005.05.007

Shephard, S., Greenstreet, S.P.R., Piet, G.J., Rindorf, A., Dickey-Collas, M. (2015) Surveillance indicators and their use in implementation of the Marine Strategy Framework Directive. ICES Journal of Marine Science 72, 2269-2277. doi:10.1093/icesjms/fsv131 
Shephard, S., Rindorf, A., Dickey-Collas, M., Hintzen, N.T., Farnsworth, K., Reid, D.G. (2014) Assessing the state of pelagic fish communities within an ecosystem approach and the European Marine Strategy Framework Directive. ICES Journal of Marine Science 71, 1572-1585. doi:10.1093/icesjms/fsu005

Sherman, K. (1991) The large marine ecosystem concept - research and management strategy for living marine resources. Ecological Applications 1, 349-360. doi:10.2307/1941896.

Sherman, K., Duda, A.M. (1999) An ecosystem approach to global assessment and management of coastal waters. Marine Ecology Progress Series 190, 271-287. doi: $10.3354 /$ meps 190271

Skern-Mauritzen, M., Ottersen, G., Handegard, N.O., et al. (2016) Ecosystem processes are rarely included in tactical fisheries management. Fish and Fisheries 17, 165-175. doi: 10.1111/faf.12111

STECF, (Scientific, Technical and Economic Committee for Fisheries) (2016) The 2016 Annual Economic Report on the EU Fishing Fleet (STECF 16-11). 470pp.

Stock, C.A., John, J.G., Rykaczewski, R.R., et al. (2017) Reconciling fisheries catch and ocean productivity. Proceedings of the National Academy of Sciences of the United States of America 114, E1441-E1449. doi:10.1073/pnas.1610238114

Trenkel, V.M., Daurès, F., Rochet, M.-J., Lorance, P. (2013) Interannual variability of fisheries economic returns and energy ratios is mostly explained by gear type. PLoS ONE 8, e70165. doi:10.1371/journal.pone.007016

Trenkel, V.M., Hintzen, N.T., Farnsworth, K.D., et al. (2015) Identifying marine pelagic ecosystem objectives and indicators for management. Marine Policy 55, 23-32. doi:10.1016/j.marpol.2015.01.002

Trenkel, V.M., Huse, G., MacKenzie, B., et al. (2014) Comparative ecology of widelydistributed pelagic fish species in the North Atlantic: implications for modelling climate and fisheries impacts. Progress in Oceanography 129, 219-243. doi:10.1016/j.pocean.2014.04.030

Trenkel, V.M., Rochet, M.-J. (2003) Performance of indicators derived from abundance estimates for detecting the impact of fishing on a fish community. Canadian Journal of Fisheries and Aquatic Sciences 60, 67-85. doi:10.1139/F02-163

Witherell, D., Pautzke, C., Fluharty, D. (2000) An ecosystem-based approach for Alaska groundfish fisheries. ICES Journal of Marine Science 57, 771-777. doi:10.1006/jmsc.2000.0719 
Figures

Fig. 1. Flow diagram for ecosystem-based single species catch advice in an MSY framework accounting for maintaining overall ecosystem productivity. MMSY is total MSY for all species including unmanaged species; MTC is total allowable catch for all species in a given year. Boxes with continuous lines contain steps that are on the spatial scale of individual stocks while steps within the dashed box are on the LME scale.
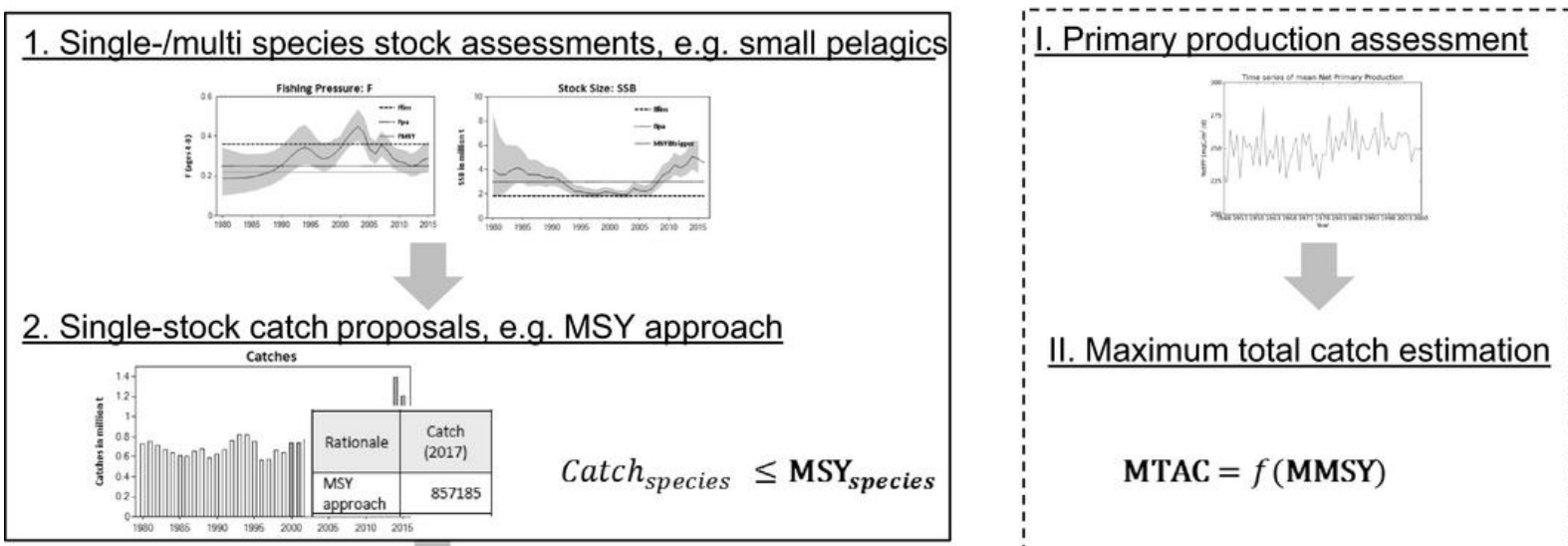

3. Catch proposal adjustements to include ecosystem objectives

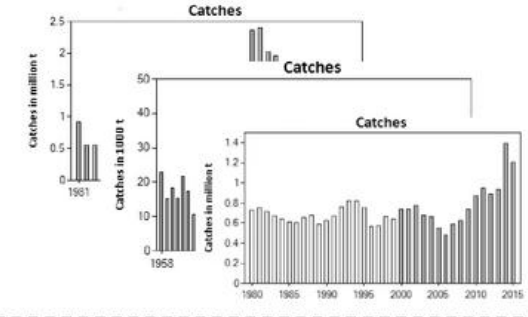

$$
\sum \text { Catch }_{\text {species }}^{*} \leq \text { MTAC }
$$

4. Ecosystem-based single species catch advice 
Fig. 2. International landings for small species $(<1 \mathrm{~kg})$ compared to MMSY reference points for two fishery selection patterns (scenarios A and C in Jennings and Collingridge (2015), see text). The reference points express multispecies sustainable yield based on system productivity.

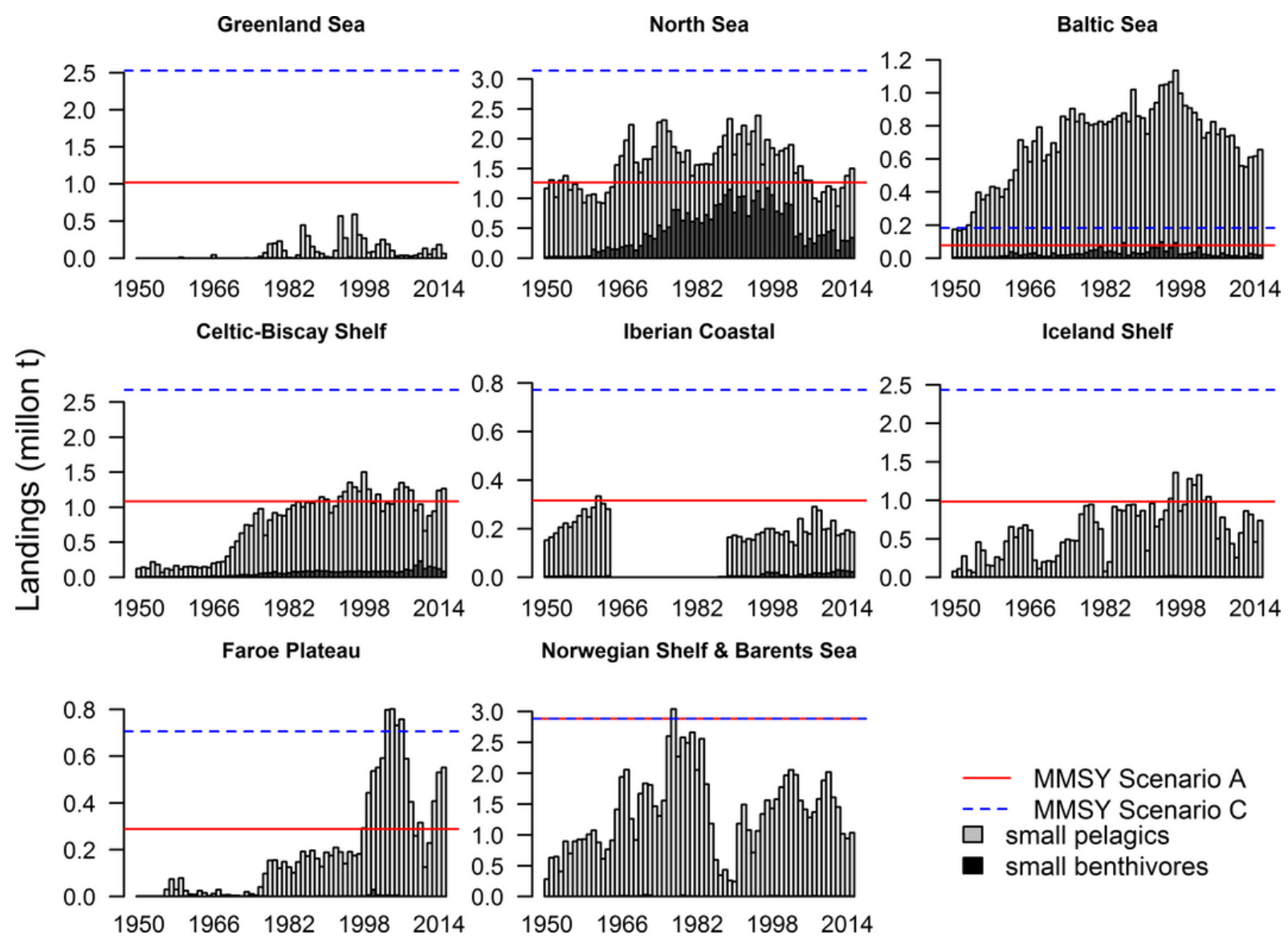


Fig 3. Ratio of landings between small species $(<1 \mathrm{~kg})$ and medium sized species $(1-10 \mathrm{~kg})$ by LME. Horizontal lines indicate reference values based on MMSY ratios for two fishery selection patterns.
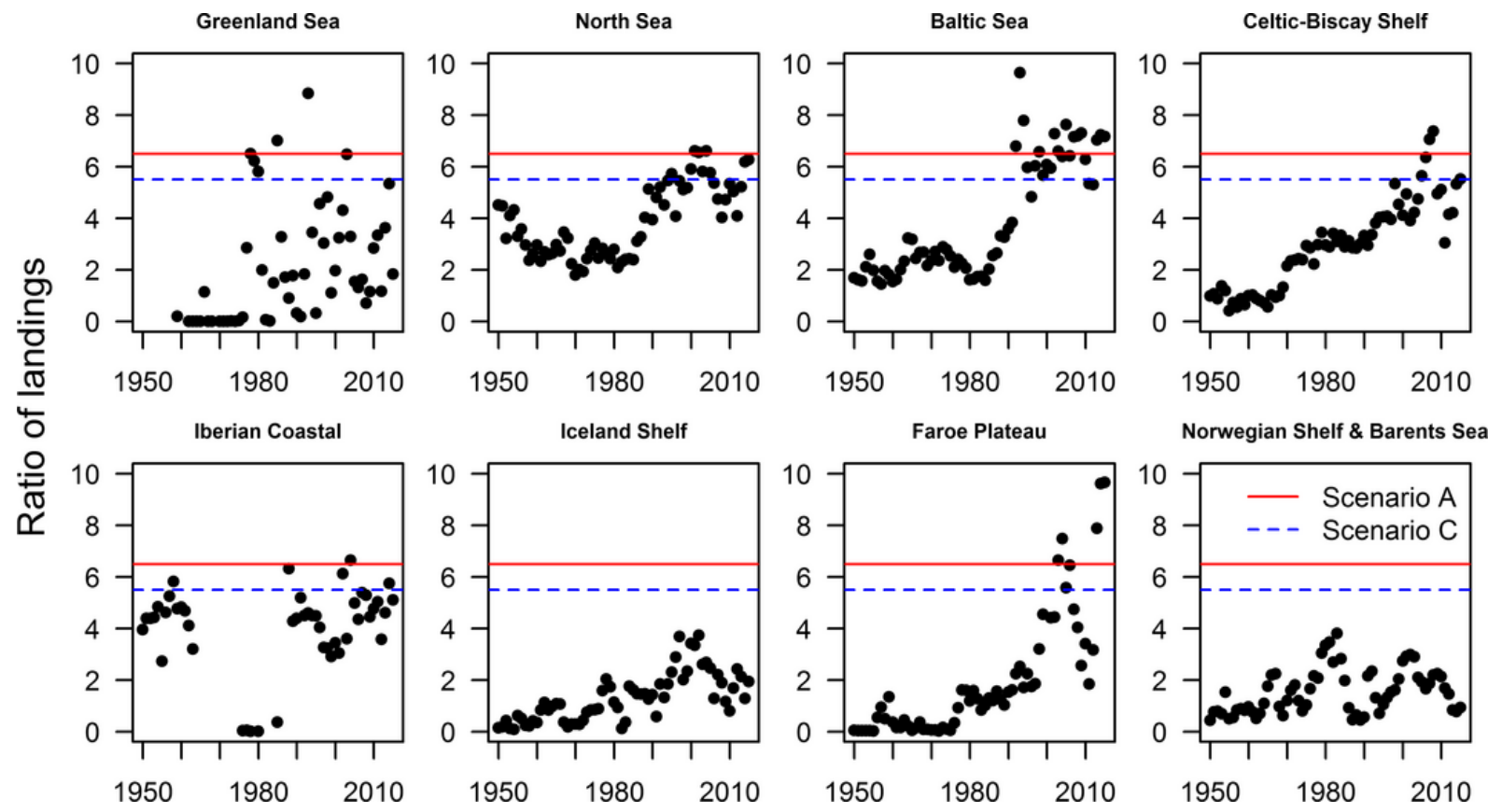


\section{Supplementary material}

Trenkel Ecosystem-based management of small pelagics: we can provide scientific advice now!

Table S1. Mean annual landings in tons by LME for the period 2010-2015 for small benthivores $(<1 \mathrm{~kg})$.

\begin{tabular}{|c|c|c|c|c|c|c|c|c|}
\hline Species & $\begin{array}{l}\text { Greenl } \\
\text { and } \\
\text { Sea } 19\end{array}$ & North Sea 22 & $\begin{array}{l}\text { Baltic Sea } \\
23\end{array}$ & $\begin{array}{l}\text { Celtic- } \\
\text { Biscay } \\
\text { Shelf } \\
24 \\
\end{array}$ & $\begin{array}{l}\text { Iberian } \\
\text { Coastal } \\
25\end{array}$ & $\begin{array}{l}\text { Iceland } \\
\text { Shelf } \\
59\end{array}$ & $\begin{array}{l}\text { Faroe } \\
\text { Plateau6 } \\
0\end{array}$ & $\begin{array}{l}\text { Norwegian } \\
\text { Shelf \& } \\
\text { Barents Sea } \\
2021\end{array}$ \\
\hline Ammodytes spp & & 296282.8 & 10863 & 178.3 & 158.9 & 0.2 & $<0.1$ & 0.2 \\
\hline Aspitrigla cuculus & & 229.1 & $<0.1$ & 3789.4 & 298.3 & & 18.5 & $<0.1$ \\
\hline Balistidae & & $<0.1$ & & 7.7 & 18.4 & & & \\
\hline Boops boops & & $<0.1$ & & 135.2 & 9476.4 & & $<0.1$ & $<0.1$ \\
\hline Boreogadus saida & & 0.3 & & $<0.1$ & $<0.1$ & & & 7841 \\
\hline Bothidae & & $<0.1$ & $<0.1$ & 0.3 & 148.8 & & & \\
\hline Callionymus lyra & & & & 0.1 & & & & \\
\hline Cancer pagurus & & 13916.6 & 342.1 & 30549.9 & 23.8 & 1.2 & 1.2 & 3987.3 \\
\hline Capros aper & & 291.7 & & 62869.2 & 0.4 & & $<0.1$ & \\
\hline Cepola macrophthalma & & & & 0.4 & 34.7 & & & \\
\hline Chelidonichthys lastoviza & & $<0.1$ & & 71.4 & & & & \\
\hline Chelidonichthys obscurus & & & & & 16.6 & & & \\
\hline Citharus linguatula & & & & 0.1 & & & & \\
\hline Dicologlossa cuneata & & & & 616.6 & 492.2 & & & $<0.1$ \\
\hline Diplodus annularis & & & & & 62.2 & & & \\
\hline Diplodus cervinus & & & & 0.4 & 20.8 & & & \\
\hline Diplodus sargus & & & & 279.5 & 967 & & & $<0.1$ \\
\hline Diplodus vulgaris & & & & & 419.1 & & & \\
\hline Eutrigla gurnardus & & 692.1 & 17.9 & 356.1 & 0.4 & 1.8 & 27.2 & 1.9 \\
\hline Gadiculus argenteus & & 800.2 & $<0.1$ & 0.2 & & & & $<0.1$ \\
\hline Gaidropsarus spp & & $<0.1$ & & 145.7 & 6.2 & & $<0.1$ & \\
\hline Glyptocephalus cynoglossus & $<0.1$ & 910.7 & 1050.3 & 3930.1 & 11.7 & 1271 & 132.8 & 19.9 \\
\hline Haemulidae (=Pomadasyidae) & & & & $<0.1$ & 49.4 & & 0 & \\
\hline Helicolenus dactylopterus & & 1.7 & & 1680.8 & 714.9 & & 7.3 & $<0.1$ \\
\hline Hippoglossoides platessoides & $<0.1$ & 11 & 3.3 & 1.3 & $<0.1$ & 124.5 & $<0.1$ & 2376.5 \\
\hline Homarus gammarus & & 2035.5 & 42.4 & 2763.4 & 15 & 423.5 & $<0.1$ & 20.6 \\
\hline Labridae & & 0.1 & & 34.2 & 178.4 & & & 0.5 \\
\hline Labrus bergylta & & 90 & 29.5 & 257.7 & 107.1 & & & 34 \\
\hline Limanda limanda & $<0.1$ & 5647.3 & 1944.4 & 1272.6 & $<0.1$ & 564.5 & 14.5 & 195.7 \\
\hline Lithognathus mormyrus & & & & 66.7 & 137 & & & \\
\hline Macroramphosus scolopax & & & & & 2.6 & & & \\
\hline Maja squinado & & 2.8 & $<0.1$ & 5682.9 & 314 & & & 0.8 \\
\hline Microchirus variegatus & & 0.7 & & 61.7 & 102.8 & & & $<0.1$ \\
\hline Microstomus kitt & $<0.1$ & 3007 & 335.8 & 4154.6 & $<0.1$ & 1704 & 219.8 & 26.2 \\
\hline Mora moro & & $<0.1$ & & 81.6 & 13.1 & & 1 & \\
\hline Moridae & $<0.1$ & 0.2 & & 0.3 & & & 3.8 & 0.1 \\
\hline Mugil cephalus & & & & & 96.1 & & & \\
\hline Mugilidae & & 96.4 & 14.2 & 231.2 & 155.3 & & $<0.1$ & \\
\hline Mullus barbatus & & & & 621.6 & 129.7 & & & \\
\hline Mullus spp & & 2.6 & & 219.4 & 242.6 & & & \\
\hline Oblada melanura & & & & 14.3 & 354 & & & \\
\hline Pagellus acarne & & $<0.1$ & & 49.8 & 1215 & & & $<0.1$ \\
\hline Pagellus erythrinus & & $<0.1$ & & 26.4 & 268.5 & & $<0.1$ & $<0.1$ \\
\hline Palinurus elephas & & & & 24.6 & 9 & & & \\
\hline Palinurus mauritanicus & & & & 1.6 & $<0.1$ & & & \\
\hline Phycis phycis & & & & 1906.8 & 465.4 & & 1.5 & \\
\hline Plectorhinchus mediterraneus & & & & $<0.1$ & 181.6 & & & \\
\hline Pleuronectiformes & 1.3 & 7.7 & $<0.1$ & 29.3 & 136.1 & 6 & $<0.1$ & 6 \\
\hline Sarpa salpa & & & & 19.7 & 782.8 & & & \\
\hline Scyliorhinidae & & 3 & & 648.2 & 58.3 & & 0.3 & \\
\hline Scyliorhinus canicula & & 292.8 & & 5616 & 418 & & $<0.1$ & \\
\hline Solea lascaris & & 0.7 & & 277.5 & 141.8 & & & \\
\hline Solea senegalensis & & $<0.1$ & & 56.7 & & & & \\
\hline Spondyliosoma cantharus & & 12.3 & & 3594.8 & 751.1 & & $<0.1$ & \\
\hline Trachinus draco & & 5.5 & 1236.4 & 345 & 36.8 & & $<0.1$ & $<0.1$ \\
\hline Trigla lyra & & & & 0.6 & 18.4 & & $<0.1$ & \\
\hline Trigla spp & & $<0.1$ & & $<0.1$ & 18.3 & & $<0.1$ & $<0.1$ \\
\hline Triglidae & & 286 & 14 & 1568.8 & 756.2 & $<0.1$ & 19.4 & $<0.1$ \\
\hline Trisopterus luscus & & 258.9 & $<0.1$ & 6433 & 4124.7 & & $<0.1$ & \\
\hline Trisopterus minutus & & $<0.1$ & $<0.1$ & 3.8 & 12.9 & & & $<0.1$ \\
\hline
\end{tabular}


Table S2. Mean annual landings in tons by LME for the period 2010-2015 for small planktivores $(<1 \mathrm{~kg})$.

\begin{tabular}{|c|c|c|c|c|c|c|c|c|}
\hline Species & $\begin{array}{l}\text { Greenland } \\
\text { Sea } 19\end{array}$ & $\begin{array}{l}\text { North Sea } \\
22\end{array}$ & $\begin{array}{l}\text { Baltic Sea } \\
23\end{array}$ & $\begin{array}{l}\text { Celtic-Biscay } \\
\text { Shelf } \\
24\end{array}$ & $\begin{array}{l}\text { Iberian } \\
\text { Coastal } \\
25\end{array}$ & $\begin{array}{l}\text { Iceland } \\
\text { Shelf } \\
59\end{array}$ & $\begin{array}{l}\text { Faroe } \\
\text { Plateau } \\
60\end{array}$ & $\begin{array}{l}\text { Norwegian } \\
\text { Shelf \& } \\
\text { Barents Sea } \\
2021\end{array}$ \\
\hline Alosa alosa & & & & 5.8 & 43.4 & & & \\
\hline Alosa fallax & & 0.4 & 7.8 & 1.1 & 122 & & & \\
\hline Alosa spp & & 0.5 & & $<0.1$ & 17.7 & & & \\
\hline Argentina silus & & 346.5 & $<0.1$ & 2666.4 & & & 31.6 & 74.2 \\
\hline $\begin{array}{l}\text { Argentina } \\
\text { sphyraena }\end{array}$ & & 1343.3 & & 869.9 & & & & 10.3 \\
\hline Argentina spp & 645.7 & 5 & $<0.1$ & 3251 & 4.6 & 6063.5 & 12275.2 & 11828.9 \\
\hline $\begin{array}{l}\text { Aristeus } \\
\text { antennatus }\end{array}$ & & & & & 50.3 & & & \\
\hline Belone belone & & 17.2 & 446.1 & 66.3 & 200.9 & & & $<0.1$ \\
\hline Clupea harengus & 7938.4 & 355825.3 & 299038.2 & 81531.9 & 23.2 & 127979.8 & 32372.8 & 685945 \\
\hline $\begin{array}{l}\text { Coryphaenoides } \\
\text { rupestris }\end{array}$ & 958 & 180.3 & 2.1 & 1028 & $<0.1$ & 36.6 & 379.9 & 12.2 \\
\hline $\begin{array}{l}\text { Engraulis } \\
\text { encrasicolus }\end{array}$ & & 1156.3 & 186.5 & 10986.9 & 13833.4 & & & $<0.1$ \\
\hline Illex coindetii & & $<0.1$ & & $<0.1$ & 50.7 & & & \\
\hline Illex illecebrosus & 9.2 & 3.2 & $<0.1$ & 2010.8 & 3283.9 & & 45.2 & \\
\hline Illex spp & & & & 652.2 & 5.1 & & & \\
\hline Mallotus villosus & 21609.1 & $<0.1$ & $<0.1$ & 0.3 & $<0.1$ & 338440.9 & 19253.3 & 261735.7 \\
\hline $\begin{array}{l}\text { Micromesistius } \\
\text { poutassou }\end{array}$ & 206 & 17745.8 & 93.5 & 345208.6 & 15827.3 & 6637.8 & 272335.7 & 44016.4 \\
\hline Mola mola & & & & 1.5 & $<0.1$ & & & \\
\hline $\begin{array}{l}\text { Osmerus } \\
\text { eperlanus }\end{array}$ & $<0.1$ & 171.5 & 3321 & 71 & $<0.1$ & & $<0.1$ & 19.7 \\
\hline Perciformes & & 15.8 & $<0.1$ & 152.1 & 37.6 & $<0.1$ & $<0.1$ & $<0.1$ \\
\hline $\begin{array}{l}\text { Sardina } \\
\text { pilchardus }\end{array}$ & & 156.6 & 5.8 & 41611.7 & 52507.7 & & & 0.1 \\
\hline Sardinella spp & & 0.2 & & $<0.1$ & 3.1 & & & \\
\hline $\begin{array}{l}\text { Scomber } \\
\text { scombrus }\end{array}$ & 33874.1 & 284730.3 & 905.8 & 215531 & 26944.9 & 126690.8 & 21532.5 & 314781.4 \\
\hline Scomber spp & & & & 0.1 & 5902.8 & & & \\
\hline $\begin{array}{l}\text { Scomberesox } \\
\text { saurus }\end{array}$ & & & $<0.1$ & 11.9 & 637.4 & & & \\
\hline Scombridae & & & & 72.3 & 2569.4 & & $<0.1$ & \\
\hline Sebastes mentella & 34946.6 & 43.1 & 0.2 & 0.3 & 7.3 & 7340.7 & 2.8 & 11889.9 \\
\hline Sprattus sprattus & & 153263 & 287987.2 & 10872.3 & 0.3 & 0 & 340.5 & 62.8 \\
\hline $\begin{array}{l}\text { Trachurus } \\
\text { mediterraneus }\end{array}$ & & & & 408.2 & 157.1 & & & \\
\hline $\begin{array}{l}\text { Trachurus } \\
\text { picturatus }\end{array}$ & & & & 0.1 & 2092.3 & & & \\
\hline Trachurus spp & & 959.1 & 111.5 & 53305.7 & 20507.8 & $<0.1$ & 11.3 & \\
\hline $\begin{array}{l}\text { Trachurus } \\
\text { trachurus }\end{array}$ & $<0.1$ & 11918 & 708.3 & 93010.1 & 24994.5 & $<0.1$ & 81.8 & 425 \\
\hline $\begin{array}{l}\text { Trisopterus } \\
\text { esmarkii }\end{array}$ & & 59862.6 & 1799.2 & 2.7 & & 134.8 & 713.5 & 6.4 \\
\hline
\end{tabular}

